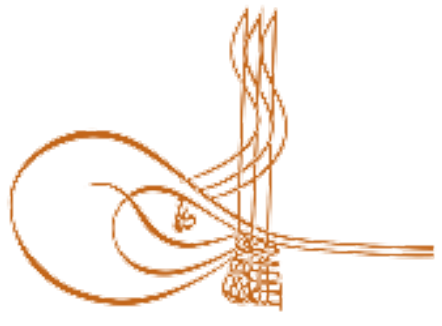

www.turkishstudies.net/education
Turkish Studies - Educational Sciences

eISSN: $2667-5609$

Research Article / Araştırma Makalesi

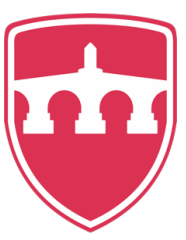

INTERNATIONAL BALKAN

UNIVERSITY Sponsored by IBU

\title{
Özel Yetenekli Çocuk Okurların "Boğaziçi’nde Saklambaç” Adı Esere Yönelik Görüşlerinin Çocuk Edebiyatının Temel İlkelerine Göre İncelenmesi
}

\author{
Investigation of the Opinions of Gifted Child Readers for the Work Named Boğaziçinde Saklambaç \\ According to the Basic Principles of Children Literature
}

\author{
Neslihan Yildı* - Serdar Derman ${ }^{* *}$
}

\begin{abstract}
The process of acquiring and developing the native language of the individual is directly related to the literature of that language. Therefore, the quality of teaching Turkish is related to the level of utilization of children's literature. Literature for children claims to be a literature specific to the child, reflecting the child's perspective, appropriate to the reality of the child and convenient for the child. In this research, semi-structured interview technique, one of the qualitative research methods, was used. Questions asked to participants were predetermined and open-ended. The research is limited to 10 students attending Science and Art Centers and receiving 4 th grade education in formal education and the data obtained from the questions asked during the interview. The data were collected in the first semester of the 2019-2020 academic year. The data were analyzed with descriptive analysis approach. According to the findings of the study, the students liked the exciting and interesting parts of the book and the title; they found the book immersive. The students stated that the book is an easy-to-understand book, contributing to vocabulary, giving messages about tolerance and common sense, arousing a sense of curiosity in themselves, and wanting to read the author's other works. The students who indicated that this book was of interest and that they could recommend it to their friends stated that they did not like the end of the work by claiming that the plot in the book did not end clearly and did not result in the plot. The students identified with the heroes in the book and think that the events in the book set an example for common sense, responsibility and tolerance. As a result, it can be said that Mina Tansel's work named Boğaziçinde Saklambaç conformed to the basic principles of children's literature and that child readers liked the work.
\end{abstract}

Veriler 2019-2020 eğitim öğretim yılının ilk döneminde toplanmıştır.

The data were collected in the first semester of the 2019-2020 academic year.

* Öğretmen, Konya Bilim ve Sanat Merkezi, Türkçe Eğitimi

Teacher, Konya Science and Art Center, Turkish Education

ORCID 0000-0002-4674-2750

neslihan.yildiz.42@hotmail.com.tr

** Dr. Ögretim Üyesi, Necmettin Erbakan Üniversitesi, Eğitim Fakültesi, Türkçe Eğitimi

Asts. Prof., Necmettin Erbakan Univercity, Faculty of Education, Turkish Education

ORCID 0000-0001-6209-0249

serdarderman@gmail.com

Cite as/ Atıf: Yıldız, N. \& Derman, S. (2020). Özel yetenekli çocuk okurların "Boğaziçi’nde Saklambaç" adlı esere yönelik görüşlerinin çocuk edebiyatının temel ilkelerine göre incelenmesi, Turkish Studies - Education, 15(2), 13811397. https://dx.doi.org/10.29228/TurkishStudies.40453

Received/Geliş: 07 January/Ocak 2020

Accepted/Kabul: 28 April/Nisan 2020

Checked by plagiarism software

Copyright $(C$ INTAC LTD, Turkey 
Structured Abstract: Human characteristics in different areas of development interact with each other. For example, language development affects thought development and is influenced by thought development. For this reason, teachers are expected to take into account that a student's acquisition will affect another area in the student's development. The vocabulary of gifted children is richer than their peers. In particular, they show superiority in using meaningful and appropriate words with abstract meaning. It is seen that gifted children use words and expressions correctly as adults would expect from older children. They are surprised by the advanced words and expressions they use, they know more words than their peers, and they can use them correctly by remembering new words. For this reason, thoughts and criticisms of gifted students about children's literature products guide teachers working with gifted students.

Children's literature is a literary genre that aims to tell the child's feelings and thoughts according to the age group that regulates the child's relationships. Children's literature covers all childhood periods starting from early childhood, embraces the child as a whole by discussing their sensitivity and experiences. Works for children require great care and attention. The artist who writes books for children should consider the reality of the child and the education of the child and form his/her work by considering these elements.

In this study, it is aimed to examine the views of gifted child readers on the book titled Boğaziçinde Saklambaç according to the basic principles of children's literature. The basis of the study was based on the principles of relativity, child reality and identification with the child within the scope of the book's content analysis.

The problem sentence of the research was determined as "What are the views of gifted child readers about the book Boğaziçinde Saklambaç according to the basic principles of children's literature?

The sub-problems in the research are:

1- According to the principle of relativity to children, what are the views of gifted children's readers about Boğaziçinde Saklambaç?

2- $\quad$ According to the principle of child reality, what are the views of gifted children's readers about Boğaziçinde Saklambaç?

3- According to the principle of identification, what are the views of gifted children's readers about Boğaziçinde Saklambaç?

In this research, interview technique which is one of the qualitative research methods was used. It is possible to classify the interview technique as structured, semi-structured and unstructured interviews. Interviews can be divided into three types: structured, semi-structured and unstructured according to the rigidity of the rules applied. The semi-structured interview has the advantages of ease of analysis, the possibility of self-expression to the interviewee and providing in-depth information when necessary.

In this research, semi-structured interview technique was used. Questions asked to participants were predetermined and all questions were open ended. The research was conducted with 10 students at the 4th grade level in the Science and Arts Center, which is an institution that provides education only to talented students. 10 students form 2 classes in the Science and Art Center.

Face to face interviews were conducted with 10 students. It was provided that the data obtained from the interview was recorded by taking notes on semi-structured interview form on the disturbance of students' video and audio recording. Each of the interviews lasted approximately 20 minutes. In the interviews conducted on a voluntary basis, it was assumed that the students understood all the questions and answered them sincerely. The data were collected in the first semester of the 2019-2020 academic year.

The data were analyzed with descriptive analysis approach. The data obtained according to this approach are summarized and interpreted according to the previously determined themes. The data can be organized according to the themes revealed by the research questions or by considering the questions or dimensions used in the interview and observation processes. In this study, direct quotations are frequently included in order to clearly reflect the opinions of the interviewees.

The following results were obtained from the answers to the questions directed to the students according to the principle of relativity to the child: 
The students liked the exciting and interesting parts of the book and the title; they found the book immersive. Students stated that the book is an easy-to-understand book in terms of the fact that the number of words they don't know the meaning of is low or not, the names are not foreign and the events are explained in detail, and that it contributes to the vocabulary, the book gives the message of tolerance and common sense and they wanted to read other works of the author. The students who said that this book was of interest to them and that they could recommend it to their friends stated that they did not like the end of the book because it was not clear. Accordingly, it can be said that Mina Tansel's book named Boğaziçinde Saklambaç is a book in accordance with the principle of relativity to the child.

The following results were obtained from the answers to the questions directed to the students according to the principle of child reality:

Students were able to correctly analyze the spiritual characteristics of the heroes in the book, and the book changed the students' view of daily life in a positive way in terms of taking adult warnings into consideration, sense of responsibility and sense of history. But the students stated that it was unrealistic for a city to talk and children to walk around a city without adults.

The following results were obtained from the answers to the questions directed to the students according to the principle of identification:

The students thought that the events in the book are examples of common sense, responsibility and tolerance. Female students felt close to Burcu because of her warmth and good behavior to her friends; the male students felt close to Emre because of his calm and discreet behavior. It may also be thought that this may be due to the students' identification with their fellows due to their age.

According to the results of the research, the following are recommended:

1- Similar studies can be done about the other works of the author.

2- $\quad$ A more comprehensive study can be done about the same book with the Science and Art Center students in terms of age group.

3- $\quad$ This study may be carried out in formal education institutions.

4- $\quad$ This study can be conducted with Turkish teachers and a comparative study can be done with the data obtained from children's readers.

5- $\quad$ The book can be included in the list of recommended works of the Ministry of National Education because it complies with the basic principles of children's literature.

Keywords: Turkish Education, Children's Literature, Child Relativity, Child Readers, Special Skill, Giftedness.

Öz: Dil öğretimi, edebiyattan bağımsız değildir. Ortaokul düzeyinde dil etkinliklerinin nitelikli bir biçimde uygulanabilmesinin ön koşullarından biri de derslerde kullanılan metnin çocuğun yaşına, bilişsel ve zihinsel, duygu dünyasına, ilgilerine kısacası çocuk edebiyatı ölçütlerine uygun ve uyumlu olmasıdır. Çocuklar için edebiyat, çocuğa özgü, çocuk bakışını yansıtan, çocuk gerçekliğine uygun ve çocuğa göre bir edebiyat olmak iddiasındadır. Bu çalışma ile özel yetenekli çocuk okurların Mina Tansel'e ait Boğaziçi'nde Saklambaç adlı esere yönelik görüşlerinin çocuk edebiyatının temel ilkelerine göre incelenmesi amaçlanmıştır. Çalışmanın temeli kitabın içerik bakımından incelenmesi kapsamında çocuğa görelik, çocuk gerçekliği ve özdeşim kurma ilkelerine dayandırılmıştır. Mina Tansel, başta "Boğaziçi'nde Saklambaç"ın yanında “İstanbul'la Saklambaç" ve "Büyüyünce Ne Olacaksın?" adlı yapitlarıyla da çok okunan, çok satılan, popüler çocuk kitapları yazarlarındandır. Yapılan alanyazın taraması sonucunda yazarın eserleri hakkında yönelik çalışmaya rastlanmamıştır. Araştırma, popüler çocuk edebiyatının öenmli yapıtlarından biri üzerine okur-çocuk gözünden görüşler sunması yönüyle önem taşımaktadır. $\mathrm{Bu}$ araştırmada nitel araştırma yöntemlerinden yarı yapılandırılmış görüşme tekniği kullanılmıştır. Katılımcılara sorulan sorular önceden belirlenmiştir ve sorular açık uçludur. Araştırma, Konya Bilim ve Sanat Merkezine devam eden ve örgün eğitimde 4. sınıf düzeyinde eğitim alan 10 öğrenciyle ve görüşmede sorulan sorulardan elde edilen verilerle sınırlıdır. Araştırma verileri betimsel analiz yaklaşımıyla analiz edilmiştir. Veriler 2019-2020 eğitim öğretim yılının ilk döneminde 
toplanmıştır. Araştırmanın bulgularına göre, öğrenciler kitabın heyecanlı ve ilginç olan, merak uyandıran bölümlerini ve başlığı sevmişler; kitabı sürükleyici bulmuşlardır. Öğrenciler, kitabın kolay anlaşılır bir kitap olduğunu, söz varlığına katkıda bulunduğunu, kitabın hoşgörü ve sağduyu ile ilgili mesajlar verdiğini, kitabın kendilerinde merak duygusu uyandırdığını, yazarın diğer eserlerini de okumak istediklerini ifade etmişlerdir. Bu kitabın ilgi alanlarına girdiğini ve arkadaşlarına tavsiye edebileceklerini belirten öğrenciler, kitaptaki olay örgüsünün net bir biçimde sonlanmadığını, olay örgüsünün beklentilerine göre sonuçlanmadığını ileri sürerek eserin sonunu beğenmediklerini ifade etmişlerdir. Öğrenciler kitaptaki kahramanlarla özdeşim kurmuşlardır ve kitaptaki olayların sağduyu, sorumluluk ve hoşgörüye örnek oluşturduğunu düşünmektedirler. Sonuç olarak Mina Tansel'in Boğaziçi'nde Saklambaç adlı eserinin çocuk edebiyatının temel ilkelerine uygun olduğu ve çocuk okurların eseri beğendikleri söylenebilir.

Anahtar Kelimeler: Türkçe Eğitimi, Çocuk Edebiyatı, Çocuğa Görelik, Çocuk Okurlar, Özel Yetenek, Üstün Zekâ

\section{Giriş}

\subsection{Problem Durumu}

Dil öğretimi, edebiyattan bağımsız değildir. Metin temelli, işlevsel ve bağlamsal dil öğretim yaklaşımları günümüzde öne çıkan ve yaygın olarak başvurulan uygulama biçimleridir. Türkçe dersi öğretim programlarında dil öğretiminin bilgiden ziyade uygulamalı olarak ve metne dayalı yapılması sıklıkla vurgulanan hususlardır. Ortaokul düzeyinde dil etkinliklerinin nitelikli bir biçimde uygulanabilmesinin ön koşullarından biri de derslerde kullanılan metnin çocuğun yaşına, bilişsel ve zihinsel, duygu dünyasına, ilgilerine kısacası çocuk edebiyatı ölçütlerine uygun ve uyumlu olmasıdır. $\mathrm{Bu}$ noktada Türkçe derslerinde gündelik yaşamdan alınan yazılı, sesli ve görsel birçok metin kullanılabilmekle beraber bu derslerdeki asıl ağırlık Türkçenin inceliklerini ve güzelliklerini estetik bir şekilde yansıtan edebiyat metinlerindedir. Türkçe öğretiminin kapsamı ve niteliği, içerikte çocuk edebiyatından ne düzeyde faydalanıldığıyla ilişkilidir. Bu nedenle dil öğretiminde, temel dil becerileri olan dinleme, konuşma, okuma, yazma ve bunun yanında dil bilgisi öğretimi süreçlerinde edebiyat ürünlerinden yararlanılır. Ana dil bilinci çocuk, aile, öğretmen, yazar ve toplumun bu yöndeki tutumları ve düzeyleri ile sarmal bir döngü oluşturur (Baş, 2015: 1-2).

Dil edinme, geliştirme ve öğrenme sürecinde çocuk edebiyatının yeri ve önemi büyüktür. Çocuklar için yazılan edebiyat eserleri çocuğun yetişkinlerden farklı olan özellikleri dikkate alınmaya başlandıktan sonra ortaya çıkmış ve çocuk edebiyatının tanımı yapılarak bu türün ilkeleri belirlenmiştir.

Çocuk edebiyatının ortaya çıkışında çocuğun etkin bir rol aldığını söyleyebiliriz. Bir anlamda çocuk, kendi zihnî yapısına uygun gelen kitaplara sahip çıkmıştır. Çocuk yapısı gereği hiçbir fikrî ve ideolojik düşüncelere itibar etmeksizin kendisine uygun bulduğu kitapları okumuş, yazarın kaygılarına ve eserinde vermek istediği mesajlara aldırmaksızın kendi bakış açısıyla bu eserleri değerlendirmiştir (Derman, 2002: 46).

Çocuk edebiyatının bugüne dek birçok tanımı yapılmıştır. Çocuk edebiyatının varlığının temelinde okur kitlesinin farklılığı vardır. Okur kitlesi farklı olduğu için içerik de amaca uygun bir biçimde farklıdır. Çocuk edebiyatının tanımlanması bu nedenle önemlidir (Hunt, 2005 :15).

Çocuk edebiyatı, erken çocukluk döneminden başlayıp ergenlik dönemini de kapsayan bir yaşam evresinde, çocukların dil gelişimi ve anlama düzeylerine uygun olarak duygu düşünce ve dünyalarını sanatsal niteliğe sahip olan dilsel ve görsel iletilerle zenginleştiren beğeni düzeylerini yükselten ürünlerin genel adıdır (Sever, 2017: 17).

Dilidüzgün'e (2004) göre, çocuk edebiyat1, okulöncesi dönem ile çocuğun ergenliğe ulaştığ1 döneme kadar olan bir zaman dilimini kapsamaktadır. Çer'e (2014: 2) göre bu dönem çocuğuna 
yönelik olarak hazırlanan kitaplarda, çocuğun doğası, bakış açısı, dil ve anlam evreni, ilgi ve gereksinmesi de göz önünde tutulmalıdır.

Dilidüzgün'e (2004) göre hitap ettiği kitle çocuk olan bir edebiyat türü konusunu da çocuğun doğal çevresinden alır. Çocuk edebiyatı ürünlerine bir edebî tür olarak bakmanın öncesinde içerik, dil, kullanılan kelimelerin seçimi, seviye gibi konularda çocuğa göre olmasına dikkat edilmelidir. Hedef kitlesi çocuk olarak belirlenerek oluşturulan edebiyatın öncelikli amacı çocuğun okumaya olan ilgi ve isteğini artırmak; onu sıkmadan düşünmeye sevk etmektir. Bu yolla çocuğun okumaya olan sevgisi gelişecektir, çocuk okuma alışkanlığını kendiliğinden edinecektir.

Bütün bunlardan anlaşılan çocuk edebiyatının kapsamının belirlenmesinde çocuğun etkin bir rol oynadığıdır. Çocuk kendi zihin yapısına uygun olan eserlere sahip çıkar. Şu hâle göre, okuyucusu çocuk olan her edebiyat ürünü, çocuk edebiyatının kapsamına girer (Ateş, 2004 :6).

Çocuklar için edebiyat, çocuğa özgü, çocuk bakışını yansıtan, çocuk gerçekliğine uygun ve çocuğa göre bir edebiyat olmak zorundadır. Çocuk kitabının tonunu yazarın biçemi belirler. Kitabın çocuğa göreliğini ise yazar çocuk ilgilerini ve çocuk gerçekliğini kavradığı oranda gerçekleştirebilir (Şirin, 2007: 42).

Çocuk edebiyatının temel ilkeleri arasında olan çocuk gerçekliği ve çocuğa görelik kavramlarını araştırmacılar şu şekilde açıklamışlardır:

Çer (2014)'e göre genel bir açıklamayla, edebî nitelik taşıyan kitaplarda çocuğa görelik; kitabın hem biçim bakımından içerik ve eğitim alanı niteliklerinin çocuğun ilgisi ve ihtiyacı, dil evreni ve anlam evreni, bakış açı ile örtüşmesi hem de yazın olma ilkelerini içinde barındırmasıdır. Ayrıntılı bir söyleyişle, çocuğa görelik; dilin ve görselin anlatım gücü, karakterin özellikleri, hareketleri, tavrı ve davranışları, iletilerin türü, konunun kapsam ve özellikleri, kurgunun seviyesi; biçim olarak; kitabın ve resimlerin boyutları, kapağının dikkat çekici olması, kullanılan kağıdın ve cildin kalitesi, sayfanın düzeni, yazı tipi, yazının puntosu, kurgudaki mantık hataları, cinsiyetçi yaklaşım, geleneksel yargılar, boş inançları kabul eden anlayış, siyasal ya da dinsel öğütler ve emirler, araştırma yapma isteğini körelten durumlarla ilgili, çocuk ile kitap arasındaki olan ilişkide, kitabın özelliklerinin hem edebî metin olma kurallarına hem de çocuk gerçekliğine uygun olmasını sağlayan tüm değişkenlerin toplamıdır.

Buna göre çocuğa uygun olan edebî bir eser oluşturmak üç değişkene bağlıdır. Kitap hem biçim bakımından hem içerik bakımından hem de içerdiği eğitsel özellikler bakımından çocuk gerçekliği ile ters düşmemelidir. Tüm bunlar gerçekleştirilirken de edebî eser, yazınsal ilkelere uygun olmalidır.

Çocuğun doğası, ilgisi, gereksinmesi, bakış açısı, yaşam deneyimleri, dil ve anlam evreni onun gerçekliğini oluşturuyorsa, bu gerçekliğin, çocuğun yaşam alanında bulunan kitaplara yansımış olması gerekir. Bu yönüyle, çocuğa sunulan kitapların onun kendi gerçekliğini yansıtmak ile ilgili kaygı taşıması gerekir. Bu kaygıyı taşımayan ve çocuğu öncelemeyen kitaplar, çocuğun gelişimini olumsuz biçimde etkileyebilir. Çocuk gerçekliği kavramı, içerisinde iki değişkeni barındırmaktadır. Bunlardan birincisi olan çocuk, tüm gelişimsel özellikleriyle ortaya çıkartılmadan bu gerçeklik açıklanamayabilir. Çünkü gerçeklik kavramı; çocuğun doğasının, bakış açısının, ilgi ve gereksinmesinin, dil ve anlam evreninin gelişimsel olarak farklılığını yansıtır. Bu yüzden, bu gerçekliğin öznesi çocuktur. Bu gerçekliği anlamak için de ilk önce çocuğun doğasının anlaşılması ve açığa çıkarılması gerekir (Çer, 2017: 13).

Arıkan (2018)'e göre kitapların konuları çocuğun ilgisine ve ihtiyacına yönelik olmalıdır. Çocuk gerçekliği ve çocuğa görelik ilkeleri de kitap seçiminde göz ardı edilmemelidir. Çünkü bu ilkeler birbirleri ile sürekli bir iletişim halindedir. 
Zeki çocuklar geniş kelime hazineleri ve gelişmiş sözlü dil becerileriyle genellikle erken gelişen sözel beceriye sahip bireyler olarak nitelendirilir (Robinson, Shore, Enersen, 2014: 49). Baz1 çocuklar, iki yaşından önce bile, üst düzey dil gelişim belirtileri sergileyebilir. Okul yılları boyunca çok okumak, iyi yazmak ve edebiyat eserleri arasındaki nüansları fark etmek gibi dil sanatlarında çok başarılıdırlar (Robinson, Shore, Enersen, 2014: 145).

Üstün yetenekli çocukların kelime dağarcıkları akranlarına göre daha zengindir. Özellikle soyut anlam taşıyan sözcükleri anlamlı ve yerinde kullanmada üstünlük gösterirler. Üstün yetenekli çocukların sözcükleri ve ifadeleri yetişkinlerin daha büyük çocuklardan bekleyeceği gibi doğru şekilde kullandığı görülür. Kullandıkları ileri düzeydeki sözler ve ifadelerle yetişkinleri şaşırtırlar, yaşıtlarına göre daha fazla kelime bilirler, yeni öğrendikleri kelimeleri hatırlayarak doğru bir şekilde kullanabilirler (Bildiren, 2011: 69).

Özel yetenekli öğrencilerin hemen hemen tamamının üstün okuyucu kategorisine girdikleri sınıf öğretmenleri tarafından da gözlemlenmiştir. Bu öğrenciler okuma alanında akranlarından 1 ila 3 yıl ileridedirler. Okumaya karşı ilgileri ve istekleri akranlarından daha fazladır ve okumaya vakit ayırmak için isteklidirler. Özel yetenekli öğrenciler okudukları kitapları anlatmayı ve eleştirmeyi severler. Kitap seçimlerini de kendileri yapmaktan hoşlanırlar. Kitap seçimlerinde kitabın kalınlığını bir kriter olarak görmezler. İlgi alanlarına yönelik olan bir kitabın kalın olmasından etkilenmeden o kitabı okuyup kısa sürede bitirirler.

Yaşıtlarına oranla yüksek düzeyde yetenek, motivasyon ve yaratıcılığa sahip olan özel yetenekli öğrencilerin ihtiyacı olan farklılaştırılmış eğitim, ülkemizde Bilim ve Sanat Merkezleri (BİLSEM) ile karşılanmaktadır. Özel yetenekli öğrncilerin dil gelişimleri, zihinsel kategori içerisindeki diğer alanların gelişimlerinde olduğu gibi yaşıtlarından farklı düzeydedir ve özel yetenekli olarak tanılanmış olan öğrenciler dil alanında da farklılaştırılmış bir eğitime ihtiyaç duymaktadırlar. Özel yetenekli öğrencilerin eğitim sürecinde, onların ilgilerinin, ihtiyaçlarının, öğrenme isteklerinin, duyarlıklarının ve algılarının dikkate alınmasının eğitim sürecinin kalitesini artırdığı bilinmektedir. Bilim ve Sanat Merkezlerinde de bu öğrencilere verilecek olan eğitim özellikler dikkate alınarak tasarlanmaktadır.

Okul öncesinden liseye kadar örgün öğretimin her kademesinde özel yetenekli öğrencilere yönelik bu merkezlerin açılabilmesi bazı ilkelere bağlıdır. Merkezin açılmasının düşünüldüğü yerleşim biriminin özellikleri, ulaşım imkânları ve hizmet alması öngörülen öğrenci sayısı gibi hususlar bu noktada etkilidir. Bilim ve Sanat Merkezleri, valiliklerin teklifi üzerine Bakanlıkça açılır (MEB, 2015: 2).

Bilim ve Sanat Merkezleri ilk olarak 1992 yılında pilot proje kapsamında Bayburt, Ankara, İstanbul, İzmir ve Denizli olmak üzere beş ilde açılmıştır.

Uyum Eğitimi, Destek Eğitimi, Bireysel Yetenekleri Fark Ettirme, Özel Yetenekleri Geliştirme ve Proje Üretimi Programı gibi beş aşamalı eğitime sahip olan bu kurumların eğitim amaçları, dünyadaki uygulamaların amaçlarına paralel olarak şekillenmiştir (Genç, 2013: 2).

BİLSEM'lerde yöntem olarak öğretmenlerin öğrencilere öğretmesinden öte, kendi seçtikleri projeler etrafında kendilerinin geliştirdikleri çözümü uygulamaları ve bu süreç içerisinde öğrenmeleri temel alınmaktadır (Levent, 2011: 56, 57).

$\mathrm{Bu}$ yolla öğrenciler onlara liderlik yapan öğretmenleri ile birlikte etkinliğin planlamasında, işleyiş̧inde ve değerlendirmesinde merkezde olan, tüm aşamaları yaşayarak öğrenen, ürün ortaya çıkaran, sorunlara çözüm üreten, eleştirel ve yaratıcı düşünebilen, bilimsel araştırma basamaklarına uygun olarak araştırma ve sonucunda proje oluşturabilen, projesini takiben buluş yapabilen ve buluşunu sunabilen bireyler olarak yetiştirilmeye çalışılmaktadır. 
Bu çalışma ile özel yetenekli çocuk okurların Boğaziçi’nde Saklambaç adlı esere yönelik görüşlerinin çocuk edebiyatının temel ilkelerine göre incelenmesi amaçlanmıştır. Çalışmanın temeli kitabın içerik bakımından incelenmesi kapsamında çocuğa görelik, çocuk gerçekliği ve özdeşim kurma ilkelerine dayandırılmıştır. Yapılan literatür taraması sonucunda yazarın eserleri hakkında ve Bilim ve Sanat Merkezlerindeki çocuk okurların görüşleri hakkında herhangi bir çalışma bulunmadığı görülmüştür. Araştırma bu yönüyle önem taşımaktadır.

\subsection{Problem Cümlesi ve Alt Problemler}

Araştırmanın problem cümlesi "Çocuk edebiyatının temel ilkelerine göre özel yetenekli çocuk okurların Boğaziçi’nde Saklambaç adlı eser hakkındaki görüşleri nelerdir?” olarak belirlenmiştir.

Araştırmadaki alt problemler şunlardır:

1- Çocuğa görelik ilkesine göre özel yetenekli çocuk okurların Boğaziçi’nde Saklambaç adlı eser hakkındaki görüşleri nelerdir?

2- Çocuk gerçekliği ilkesine göre özel yetenekli çocuk okurların Boğaziçi’nde Saklambaç adlı eser hakkındaki görüşleri nelerdir?

3- Özdeşim kurma ilkesine göre özel yetenekli çocuk okurların Boğaziçi’nde Saklambaç adlı eser hakkındaki görüşleri nelerdir?

\section{Yöntem}

\subsection{Araştırmanın Yöntemi}

$\mathrm{Bu}$ araştırmada nitel araştırma yöntemlerinden görüşme tekniği kullanılmıştır. Görüşme tekniğini kendi içinde yapılandırılmış, yarı-yapılandırılmış ve yapılandırılmamış görüşmeler olarak sinıflamak mümkündür. (Karasar, 1998, Akt. Küçükyılmaz ve Duban 2006: 5).

Görüşmeler uygulanan kuralların katılı̆̆ına göre yapılandırmış, yarı yapılandırılmış ve yapılandırılmamış olmak üzere üçe ayrılabilir. Yarı yapılandırılmış görüşmenin, analizlerin kolaylığı, görüşülene kendini ifade etme imkânı, gerektiğinde derinlemesine bilgi sağlama avantajları vardır (Karasar, 2017: 212).

$\mathrm{Bu}$ araştırmada yarı yapılandırılmış görüşme tekniği kullanılmıştır. Katılımcılara sorulan sorular önceden belirlenmiştir ve tüm sorular açık uçludur. Araştırma, Konya Bilim ve Sanat Merkezine devam eden ve örgün eğitimde 4. sınıf düzeyinde eğitim alan 10 öğrenciyle ve görüşmede sorulan sorulardan elde edilen verilerle sinırlıdır.

\section{2. Çalışma Grubu}

Çalışma grubunu 2018-2019 eğitim öğretim yılında Konya Bilim ve Sanat Merkezinde destek eğitimi alan, örgün eğitimde ise farklı ilkokulların 4. sınıfına devam eden 10 öğrenci oluşturmaktadır. Bu 10 öğrenci kurumda 5'er kişilik 2 ayrı sınıfı oluşturmaktadır. 
Tablo 1: Çalışma Grubu

\begin{tabular}{cccc}
\hline Öğrenci Kodu & Yaş & Cinsiyet & Sınıf \\
\hline Ö1 & 10 & Kız & A \\
\hline Ö2 & 11 & Erkek & A \\
\hline Ö3 & 10 & Erkek & A \\
\hline O4 & 10 & Erkek & B \\
\hline O5 & 11 & Erkek & B \\
\hline Ö6 & 10 & Kı & A \\
\hline Ö7 & 10 & Kız & B \\
\hline O8 & 10 & Kız & A \\
\hline Ö9 & 11 & Kız & B \\
\hline Ö10 & 10 & Erkek & B
\end{tabular}

Çalışma grubunu oluşturan 10 öğrenciden 3'ü 11, 7'si ise 10 yaşındadır. Çalışmanın gerçekleştirildiği iki grubu oluşturan erkek ve kız öğrencilerin toplam sayıları, Bilim ve Sanat Merkezlerinde sınıfların cinsiyet, liderlik özelliği, ilgi ve yetenek bakımından mümkün olduğu kadar homojen bir şekilde oluşturulmasından dolayı eşittir.

\subsection{Verilerin Toplanması}

Çalışma grubunu oluşturan 10 öğrenci ile yüz yüze görüşmeler yapılmış, öğrencilerin görüntü ve ses kaydı yapılmasından rahatsız olmaları üzerine görüşmeden elde edilen verilerin, yarı yapılandırılmış görüşme formu üzerine not alınarak kaydedilmesi sağlanmıştır. Görüşmelerin her biri yaklaşık 20 dakika sürmüştür. Gönüllülük esasına göre gerçekleștirilen görüşmelerde öğrencilerin tüm soruları anladıkları ve sorulara samimiyetle cevap verdikleri varsayılmıştır. Yapılan görüşmelerde aşağıdaki sorular yöneltilmiştir.

A- Çocuğa görelik ilkesine göre öğrencilere yöneltilen sorular şunlardır:

1. Boğaziçi’nde Saklambaç kitabında beğendiğiniz bölüm hangisidir? Neden?

2. Bu kitap sizde yazarın diğer eserlerini okuma isteği uyandırdı mı? Neden?

3. Bu kitabın sonunu siz yazsaydınız nasıl yazardınız?

4. Bu kitabın başlı̆̆ını siz koysaydınız bu başlık ne olurdu?

5. Bu kitabın size hangi mesajları verdiğini düşünüyorsunuz?

6. Bu kitap sizce kolay anlaşı1ır bir kitap mı? Neden?

7. Bu kitap söz varlığınıza (kelime dağarcığı, söz kalıpları vs.) katkıda bulundu mu? Açılklayınız.

8. Bu kitabı arkadaşlarınıza tavsiye eder misiniz? Neden?

9. Bu kitap okudukça merakınızı uyandırdı mı? Neden?

10. Okuduğunuz kitabı genel olarak, sebepleriyle birlikte değerlendirecek olursanız olay örgüsü hakkında ne düşünüyorsunuz? (Karmaşı, sürükleyici vs.)

11. Bu kitabın konusu ilgi alanınıza giriyor mu?

B. Çocuk gerçekliği ilkesine göre öğrencilere yöneltilen sorular şunlardır: 
1. Bu kitapta kahramanlar nasıl bir ruh hâlindedir?

2. Bu kitaptaki olaylar gerçekten yaşanmış olabilir mi? Neden?

3. Bu kitapta günlük hayata bakışınızı değiştiren bir olay/durum oldu mu? Açıklayınız.

C. Özdeşim kurma ilkesine göre öğrencilere yöneltilen sorular şunlardır:

1. Kendinizi kitaptaki bir kahramanla özdeşleştirdiniz mi? Nedenleriyle açılayınız.

2. Bu kitaptaki olaylar sizce hangi erdemli davranışa örnek oluşturur? (Sorumluluk, insan ve hayvan sevgisi, ahlak, fedakârlık, dürüstlük, kıskançlıktan uzak durma, saygı, hoşgörü, çalışkanlık, yardımseverlik vb.)

\subsection{Verilerin Analizi}

Araştırma verilerinin analizinde, betimsel analiz yaklaşımı kullanılmıştır. Çalışmanın verileri, oluşturulan temalara göre özetlenmiş ve yorumlanmıştır. "Betimsel analizde görüşülen ya da gözlenen bireylerin görüşlerini çarpıcı bir biçimde yansıtmak amacıyla doğrudan alıntılara sık sık yer verilir." ilkesine uygun olarak veriler farklı çalışmalarla desteklenmiştir. (Yıldırım, Şimşek, 2016: 239).

\section{Bulgular ve Yorum}

\subsection{Birinci Alt Probleme İlişkin Bulgular ve Yorum}

Birinci alt problem olan "Çocuğa görelik ilkesine göre, özel yetenekli çocuk okurların Boğaziçi'nde Saklambaç adlı eser hakkındaki görüşleri nelerdir?" sorusu kapsamında öğrencilere yöneltilen sorular ve cevaplar şöyledir:

1. Boğaziçi'nde Saklambaç kitabında beğendiğiniz bölüm hangisidir? Neden?

Ö1: "Beğendiğim bölüm Anadolu Hisarı'na gittikleri bölümdü. Çünkü heyecanlı bir bölümdü. Emre'nin gözlüğünün düş̧ükten sonra arkadaşlarına kızmaması da güzel bir davranıştı."

Ö2: “Ayazma dehlizine girdikleri bölümdü. Çünkü başlarına ne geleceğini çok merak ettim.”

Ö3: “Ali’nin denize atladığı bölüm. Çünkü o bölümde başlarına bir şey gelip gelmeyeceğini merak ettim."

Ö4: “Ayazma'daki dehlizde kilitli kaldıkları bölüm en sevdiğim bölümdü. Heyecanlı bir bölümdü."

Ö6: "İnsanların giremediği saray bölümünü sevdim. Çünkü kuşların böyle sarayları olduğunu bilmiyordum. Bana ilginç geldi." ettim."

Ö9: "Ben en çok kilitli kaldıkları bölümü sevdim. Oradan çıkıp çıkamayacaklarını merak

Öğrenciler en çok dehlizde kilitli kalınan bölümü, saray bölümünü, Anadolu Hisarı bölümünü sevdiklerini ifade etmişlerdir. Verilen cevaplara göre öğrenciler kitabın heyecanlı ve ilginç olan, merak uyandıran bölümlerini sevmişlerdir.

2. Bu kitap sizde yazarın diğer eserlerini okuma isteği uyandırdı mı? Neden?

Ö3: "Evet. Çünkü çok hızlı okudum. Akıcı bir kitap olmasaydı bu kadar hızlı okumazdım. Yazarın diğer kitaplarının da akıcı olduğunu düşünüyorum.”

Ö5: "Evet. Bu kitabı bir solukta okudum."

Ö8: "Bu yazarın kitabını ilk kez okudum. Diğer kitapları da böyle akıcı ise okumak isterim." 
Ö9: "Evet. Çünkü bu kitaptan hem çok şey öğrendim hem de okurken çok eğlendim. Bence diğer kitapları da böyledir."

Ö10: "Evet. Yazar çok fazla şey biliyor. Bu kadar çok bilgiye sahip bir insan kim bilir daha neler yazmıştır."

Öğrencilerin tamamı bu yazarın diğer eserlerini de okumak istediklerini belirtmişler, bunun sebebini de yeni bilgiler içermesi; akıc1, ilginç ve eğlenceli olması şeklinde ifade etmişlerdir.

3. Kitabın sonunu sevdiniz mi? Bu kitabın sonunu siz yazsaydınız nasıl yazardınız?

Ö1:" Hayır. Ali’nin doğru düzgün veda etmeden gitmesi hiç hoş olmadı. Ben böyle bitirmezdim. Arkadaşlarına sarılıp vedalaşabilirlerdi."

Ö4: "Hayır. Ben olsam bir akşam yemeğinde üç aileyi de bir araya getirir öyle bitirirdim."

Ö6: "Bu kadar çok şey yaşanan bir kitapta böyle birdenbire son yapmazdım. Vedalaşmamaları kötü oldu."

Ö7: "Hayır. Böyle çok kararsız bir son olmuş. Tüm aileleri Çanakkale’ye doğru yola çıkararak bitirirdim."

Ö8: "Hayır. Ben okuyucuya yeni bir bilmece sorar ve cevabını söylemeden bitirirdim. Böylece okuyucu bunu araştırabilirdi."

Öğrenciler kahramanların vedalaşmadan ayrılmalarından hoşlanmadıklarını ifade etmişlerdir. Verilen cevaplara göre öğrencilerin kitabın sonunu sevmedikleri ve kitabın daha net bir şekilde sonlandırılmasını istedikleri görülmüştür.

4. Bu kitabın başlığını siz koysaydınız bu başlık ne olurdu?

Ö2: "Değiştirmezdim. Bu başlık güzel."

Ö3: "Başlı̆̆1 değiştirmezdim."

Ö6: "Ben de Boğaziçi'nde Saklambaç koyardım."

Ö9: “İstanbul ile Saklambaç 2 koyardım. Çünkü Boğaziçi’nin dışına da çıkıyorlardı.”

Ö10: "Başlık çok uygun bence."

Verilen cevaplara göre 10 öğrenciden 9'unun kitabın başlı̆̆ının değişmemesi gerektiğini ifade etmiş, 1 öğrenci ise yeni bir başlık bulmuş ve bunu gerekçelendirmiştir. Genel olarak öğrencilerin kitabın başlığını uygun buldukları söylenebilir.

5. Bu kitabın size hangi mesajları verdiğini düşünüyorsunuz?

Ö1: "Bence hoşgörü ile ilgili mesaj veriyor."

Ö2: "Kitap çocukların daha sağduyulu olması gerektiği mesajını veriyor. Ali hiç kimseyi dinlemediği için başlarına bir sürü şey geliyor."

Ö3: "Çocukların büyüklerin sözlerini daha çok dikkate almaları gerektiği mesajını veriyor. Büyükleri dinlemedikleri bölümlerde başlarına kötü şeyler geldi.”

Ö6: “Arkadaşlarımızın uyarılarını dikkate almamız gerektiği mesajını veriyor. Emre her zaman arkadaşlarını uyardı ama onlar dinlemedikleri için bir yerde az kalsın düşüyorlardı, bir yerde Ali’nin boğulduğunu sandılar, bir yerde de kilitli kaldılar." bu."

Ö7: "Kitaptaki yetişkinler çocuklara oldukça hoşgörülü davranıyorlar. Bence verilen mesaj 
Öğrenciler kitabın büyüklerin sözlerinin daha çok dikkate alınmasının gerektiği mesajını, hoşgörü ve sağduyu ile ilgili mesaj verdiğini ifade etmişlerdir.

6. Bu kitap sizce kolay anlaşılır bir kitap mı? Neden?

Ö4: "Evet. Çünkü isimler yabancı değil. İsimler yabancı isim olunca herkesi birbirine karıştırıyorum."

Ö5: "Evet. Çünkü anlamını bilmediğim kelime sayısı yok denecek kadar az."

Ö7: "Evet. Çünkü yazar olayları detaylı anlatmış."

Ö9: "Evet. Çünkü elimde sözlükle okumak zorunda kalmadım.”

Ö10: "Evet. Çünkü aynı sayfayı tekrar okutmadı. Bazı kitapları anlamadığım zaman o bölümleri tekrar okumak zorunda kalıyorum. Bu da kitap okumanın tüm zevkini yok ediyor.”

Öğrencilerin tamamı, anlamını bilmedikleri kelimelerin sayısının az olması ya da hiç olmaması, isimlerin yabancı olmaması ve olayların detaylı anlatılması yönüyle kitabın kolay anlaşı1ır bir kitap olduğunu ifade etmiştir.

7. Bu kitap söz varlığınıza (kelime dağarcığı, söz kalıpları vs.) katkıda bulundu mu? Açıklayınız.

Ö4: "Evet. Emirgan, Tarabya gibi yer isimlerinin nereden geldiğini öğrendim."

Ö6: "Evet. Sözlükten bakmadan ayazma kelimesinin ne anlama geldiğini öğrendim.”

Ö7: "Evet. Tarabya'nın adı Terapia'dan, Emirgan'ın adı da Emir Gune'den geliyormuş."

Ö9: "Evet. Ayazma ve dehliz kelimelerini öğrendim."

Ö10: "Evet. Ayazma, dehliz gibi kelimeleri öğrendim."

Öğrenciler birçok yeni kelime öğrendiklerini ve bu kitabın söz varlıklarına katkıda bulunduğunu ifade etmişlerdir.

8. Bu kitabı arkadaşlarınıza tavsiye eder misiniz? Neden?

Ö1: "Evet. Çünkü çok akıcıydı."

Ö2: "Evet. Çünkü macera dolu bir kitaptı. Macera kitaplarını herkes sever."

Ö5: "Evet. Çünkü heyecanlı bir kitaptı."

Ö8: "Evet. Çünkü akıcı bir kitaptı."

Ö9: "Evet. Çünkü arkadaşlarımın da sıkılmadan okuyacağını düşünüyorum."

Öğrencilerin tamamı kitabın heyecanlı ve akıcı olmasından dolayı bu kitabı arkadaşlarına tavsiye edebileceklerini ifade etmişlerdir.

9. Bu kitap okudukça merakınızı uyandırdı mı? Neden?

Ö1: "Evet. Çünkü hep bir sonraki saklanılacak yeri merak ettim.”

Ö2: "Evet. Çünkü heyecan doluydu."

Ö3: "Evet. Çünkü hep yeni bir macera yaşadılar."

Ö4: "Evet. Çünkü hep yeni yerler görme firsatları oldu."

Ö5: "Evet. Çünkü bir sonraki maceraları ne olacak, neler öğrenecekler diye merak ettim. Onlar öğrendikçe ben de öğrendim." 
Öğrencilerin verdikleri cevaplara göre kitap öğrencilerde bir merak duygusu oluşturmuştur.

10. Okuduğunuz kitabı genel olarak, sebepleriyle birlikte değerlendirecek olursanız olay örgüsü hakkında ne düşünüyorsunuz? (Karmaşık, sürükleyici vs.)

Ö6: "Sürükleyici. Çünkü hep bir hareket vardı."

Ö7: "Sürükleyici. Merak uyandırıcıydı."

Ö8: "Sürükleyiciydi. Heyecanlı bölümler vardı."

Ö9: "Sürükleyici diyebilirim. Akıcı bir kitaptı."

Ö10: "Sürükleyici. Ama ilk sayfalarda daha çok açıklama olmalıydı."

Öğrenciler kitabın merak uyandırıcı, akıcı, heyecanlı olduğunu ifade etmişlerdir. Verilen cevaplara göre öğrencilerin tamamı kitabı sürükleyici bulmuştur.

11. Bu kitabın konusu ilgi alanınıza giriyor mu?

Ö2: "Evet. Çünkü İstanbul'a hiç gitmedim. Gitmek istiyorum."

Ö5: "Evet. Çünkü yeni yerler hakkında bir şeyler öğrenmeyi seviyorum."

Ö6: "Evet. Hem saklambaç hem gezme var."

Ö8: "Evet. İstanbul'u seviyorum."

Ö9: "Evet. Çünkü tarih benim ilgi alanım."

Verilen cevaplara göre kitabın yeni yerler, İstanbul, oyun ve tarih ile ilgili olması nedenleriyle öğrencilerin ilgi alanına girdiği söylenebilir.

\section{2. İkinci Alt Probleme İlişkin Bulgular ve Yorum}

İkinci alt problem olan "Çocuk gerçekliği ilkesine göre, özel yetenekli çocuk okurların Boğaziçi'nde Saklambaç adlı eser hakkındaki görüşleri nelerdir?” sorusu kapsamında öğrencilere yöneltilen sorular ve cevaplar şöyledir:

1. Bu kitapta kahramanlar nasıl bir ruh hâlindedir?

Ö1: "Burcu sıcakkanlı. Ali fazlasıyla kendini beğenmiş. Emre de arada kalıyor bence."

Ö3: "Burcu iyi biri. Ali için çok endişelendi. Ali dikkatsiz ve düşünmeden hareket eden biri. Emre kimseyi kırmamaya çalışıyor."

Ö6: "Emre oldukça soğukkanlı, sakin. Burcu heyecanlı ve hareketli bir karakter. Ali ise sürekli başına dert açıyor."

Ö8: "Emre iyi kalpli. Gözlüğünün camı diğerleri yüzünden kırıldı ama o bunu sorun etmedi. Üstelik Ali'nin peşinden denize atlad. Ali sorumsuz ve duygusuz. Burcu sevecen."

Ö9: "Emre sağduyulu biri. Gereksiz tehlikelere atılmak istemiyor ama arkadaşlarını da yalnız birakmıyor. Burcu sicakkanlı. Ali fazlasıyla sorumsuz."

Öğrenciler kitaptaki karakterlerden Burcu'nun sıcakkanlı, Emre'nin sağduyulu ve Ali’nin sorumsuz olduğunu ifade etmişlerir. Verilen cevaplara göre öğrencilerin kitaptaki kahramanların ruhsal özelliklerini doğru bir şekilde analiz edebildikleri görülmektedir.

2. Bu kitaptaki olaylar gerçekten yaşanmış olabilir mi? Neden?

Ö1: “İstanbul'un konuşması hariç olabilir."

Ö4: “Olamaz. Üç çocuk İstanbul'u tek başlarına gezemez.” 
Ö5: "İstanbul'un konuşması hiç gerçekçi değil. Ama diğer kısımlar gerçek olabilir."

Ö7: "İstanbul'un konuşmasını bir kenara bırakırsak çocuklar bir şehrin tarihini oyunla öğreniyorlar. Olabilir." öğrenebilir.”

Ö10: "Bir şehrin konuşması gerçekten olamaz. Fakat çocuklar bir şehri gezip o şehrin tarihini

Verilen cevaplara göre öğrenciler kitaptaki bazı olayların gerçekten yaşanmış olamayacağını ifade etmişler, bazı olayları ise gerçekçi bulmuşlardır. Öğrencilerin ifadelerine göre; öğrencilerin İstanbul'un konuşmasını ve çocukların İstanbul'u tek başlarına gezmelerini gerçekçi bulmadıklarını fakat çocukların bir şehrin tarihini oyunla öğrenmeleri kısmını gerçekçi buldukları görülmüştür.

3. Bu kitapta günlük hayata bakışınızı değiştiren bir olay/durum oldu mu? Açıklayınız.

Ö1: “Aslında bekçiye rağmen Anadolu Hisarı'na çıktıklarında insanların uyarılarını daha çok dikkate almam gerektiğini anladım."

Ö4: "Ayazmada kilitli kalmaları büyükleri daha dikkatli dinlemem gerektiğini öğretti."

Ö6: "Ali’nin denize atlaması ve arkadaşlarının çok korkmaları bana daha sorumluluk sahibi olmam gerektiğini öğretti. Sırf canımız istedi diye aklımıza gelen her şeyi yapmamalıyız."

Ö8: "Büyükleri daha çok dinleyeceğim. Başlarına ne geldiyse ondan geldi."

Ö9: "Önünden geçip gittiğimiz bir çeşmeyi kimin yaptırdığını ya da indiğimiz durağın isminin nereden geldiğini merak etmeye başladım."

Verilen cevaplara göre kitapta öğrencilerin günlük hayata bakışlarını değiştiren olaylar veya durumlar olduğu görülmüsstür. Öğrencilerin günlük hayata bakışlarını yetişkinlerin uyarılarını dikkate alma, sorumluluk sahibi olma ve şehirdeki tarihî doku hakkında daha çok bilgi sahibi olma yönüyle değiştirdiği söylenebilir.

\section{3. Üçüncü Alt Probleme İliş̧kin Bulgular ve Yorum}

Üçüncü alt problem olan "Özdeşim kurma ilkesine göre, özel yetenekli çocuk okurların Boğaziçi'nde Saklambaç adlı eser hakkındaki görüşleri nelerdir?” sorusu kapsamında öğrencilere yöneltilen sorular ve cevaplar şöyledir:

1. Kendinizi kitaptaki bir kahramanla özdeşleştirdiniz mi? Cevabınız evet ise nedenleriyle açıklayınız.

Ö1: "Evet. Burcu'nun sıcakkanlı davranışları var. Ben de öyle olduğumu düşünüyorum."

Ö2: "Emre’ye benziyorum. Çünkü benim de sakin olduğumu söylerler."

Ö5: "Emre diyebilirim. Kimseyi kırmıyor, kızdırmıyor. Arkadaşlarını uyarmaya çalışıyor."

Ö6: "Burcu ile özdeşleştirdim. Arkadaşlarına iyi davranıyor, onların başına bir şey gelecek diye endişeleniyor ve mücadele etmeyi seviyor."

Ö10: "Kendimi Emre’ye yakın hissettim. Çünkü sağduyulu davranıyor."

Verilen cevaplara göre öğrencilerin kitaptaki karakterler ile özdeşim kurdukları, özdeşim kurmada cinsiyet farkl1lıkları oluştuğu görülmüştür. Kız öğrenciler sıcakkanlılığı ve arkadaşlarına iyi davranması gibi sebeplerle kendilerini Burcu adlı kahramana; erkek öğrenciler ise sakin ve sağduyulu davranmasından dolayı kendilerini Emre adlı kahramana yakın hissetmişlerdir.

2. Bu kitaptaki olaylar sizce hangi erdemli davranışa örnek oluşturur? (Sorumluluk, insan ve hayvan sevgisi, ahlak, fedakârlık, dürüstlük, kıskançlıktan uzak durma, saygı, hoşgörü, çalışkanlık, yardımseverlik vb.) 
Ö1: "Hoşgörü ve sorumluluk ile ilgili davranışlar vardı. Herkes hoşgörülü davranıyordu. Ali’nin sorumsuzluğu kötü sonuçlara yol açtı."

Ö3: "Sağduyu bence. Emre çok sağduyulu davrandı."

Ö5: "Sorumluluk. Çünkü ne zaman sorumsuzca davransalar başlarına kötü şeyler geldi."

Ö6: "Sorumluluk ve hoşgörü. Büyükler hoşgörülüydü. Küçükler de sorumluluk sahibi oldukları sürece güzel maceralar yaşadılar."

Ö10: "Sağduyu. Emre hep sağduyulu davrandı. Eğer onun dediklerini yapsalardı Burcu'nun dondurma yediği için karnı ağrımayacak, Ali denizde tehlike yaşamayacak, Anadolu Hisarı'nda bekçiyi zor durumda bırakmayacak ve ayazmada kilitli kalmayacaklardı."

Öğrenciler genel olarak, kitaptaki karakterlerden birinin sağduyulu davrandığını, diğer bir karakterin ise sorumluluk sahibi olduğunu ifade etmişlerdir. Verilen cevaplara göre öğrenciler kitaptaki olayların sağduyu, sorumluluk ve hoşgörüye örnek oluşturduğunu düşünmektedirler.

\section{Sonuç ve Tartışma}

\subsection{Birinci Alt Probleme İlişskin Sonuç ve Tartışma}

Çocuğa görelik ilkesine göre öğrencilere yöneltilmiş olan soruların cevaplarından hareketle şu sonuçlar elde edilmiştir:

Öğrenciler kitabın heyecanlı ve ilginç olan, merak uyandıran bölümlerini ve başlığı sevmişler; kitabı sürükleyici bulmuşlardır. Öğrenciler, anlamını bilmedikleri kelimelerin sayısının az olması ya da hiç olmaması, isimlerin yabancı olmaması ve olayların detaylı anlatılması yönüyle kitabın kolay anlaşı1ır bir kitap olduğunu, bununla birlikte söz varlığına katkıda bulunduğunu, kitabın en çok hoşgörü ve sağduyu ile ilgili mesajlar verdiğini, kitabın merak duygusu uyandırdığını, yazarın diğer eserlerini de okuma isteği uyandırdığını ifade etmişlerdir. Bu kitabın ilgi alanlarına girdiğini ve kitabı arkadaşlarına da tavsiye edebileceklerini söyleyen öğrenciler, kitabın sonunun net olmadığını ve beklentilerini karşılamadığını ifade etmişlerdir. Buna göre Mina Tansel'in Boğaziçi'nde Saklambaç adlı eserinin çocuğa görelik ilkesine uygun bir kitap olduğu söylenebilir.

Burç (2013), "Rıfat Ilgaz'ın Bacaksız'ın Basından Geçenler Adlı Hikâye Serisindeki Eserlerin Çocuğa Görelik İlkesi Açısından İncelenmesi” başlıklı çalışmasında yazarın kullandığı akıcı, açık ve anlaşılır dil sayesinde eserlerin ve eserlerdeki kahramanların kolayca benimsendiği, hikâye serisinin çocukların ilgi alanlarının içinde olduğu, çocukların hikâyeleri okurken eğlendikleri ve öğrendikleri; bahsi geçen serinin bu yönlerinin çocuğa görelik ilkesine uygun olduğu sonucuna ulaşmıştır.

Kirazlı (2018), "Behiç Ak'ın Çocuk Edebiyatı Yapıtlarının Çocuğa Görelik Açısından İncelenmesi” başlıklı çalışmasında Behiç AK'ın okulöncesi döneme uygun olan dokuz yapıtını incelemiş ve incelenen çocuk edebiyatı yapıtlarının dil ve anlatım, ileti, karakter çerçevesi, izlek, konu bakımından çocuğa görelik ilkesine uygun olduğu sonucuna ulaşmıştır.

Buna göre hem Burç'un (2013) hem de Kirazlı'nın (2018) araştırmasının sonuçları araştırmamız ile benzer sonuçlara ulaşmıştır denebilir.

\section{2. İkinci Alt Probleme İlişkin Sonuç ve Tartışma}

Çocuk gerçekliği ilkesine göre, öğrencilere yöneltilmiş olan soruların cevaplarından hareketle şu sonuçlar elde edilmiştir:

Öğrenciler kitaptaki kahramanların ruhsal özelliklerini doğru bir şekilde analiz edebilmişlerdir, kitap öğrencilerin günlük hayata bakışını yetişkinlerin uyarılarını daha çok dikkate alma, sorumluluk duygusu ve tarih bilinci bakımından olumlu yönde değiştirmiştir. Fakat öğrenciler 
bir şehrin konuşmasının ve çocukların bir şehirde yanlarında yetişkinler olmadan gezmelerinin gerçekçi olmadığını ifade etmişlerdir.

Çer (2014) "Edebiyatta Çocuk Gerçekliği ve Çocuğa Görelik İlkelerinin İncelenmesi” başlıklı çalışmasında aile sıcaklığı, paylaşma, iyilik, doğa ve insana duyulan sevginin eğlenceli, ilginç, gülünç, şaşırtıcı ve olağanüstü öğelerle duyumsatılmasının; çocukların arkadaş edinmeye yönelik olumlu tutum geliştirmelerinin, onların keşfetme ve serüven ihtiyaçlarının karşılanmasının yazınsal nitelikteki kitapların çocuk gerçekliği açısından gerekli özellikleri olduğunu ifade etmiştir.

Çalışmamızın zemini olan kitap, Çer'in (2014) temel aldığı konular bakımından incelenmiştir. Buna göre Mina Tansel'in Boğaziçi'nde Saklambaç adlı eserinin çocuk gerçekliği ilkesine kismen uygun bir kitap olduğu söylenebilir.

\section{3. Üçüncü Alt Probleme İlişkin Sonuç ve Tartışma}

Özdeşim kurma ilkesine göre öğrencilere yöneltilmiş olan soruların cevaplarından hareketle şu sonuç elde edilmiştir:

Öğrenciler kitaptaki olayların sağduyu, sorumluluk ve hoşgörüye örnek oluşturduğunu düşünmektedirler. Kız öğrenciler sıcakkanlılığı ve arkadaşlarına iyi davranması gibi sebeplerle kendilerini Burcu adlı kahramana; erkek öğrenciler ise sakin ve sağduyulu davranmasından dolayı kendilerini Emre adlı kahramana yakın hissetmişlerdir. Bu durumun öğrencilerin yaşı itibarıyla hemcinsleri ile özdeşim kurmalarından kaynaklanmış olabileceği de düşünülebilir.

Arıkan (2018), “Çocuk Edebiyatının Temel İlkeleri Bakımından Memduh Şevket Esendal'ın Öykülerinin Öğrenci Görüşlerine Göre Değerlendirilmesi” başlıklı çalışması kapsamında yaptığı görüşmeler sonucunda ögrrencilerin öykünün ana kahramanıyla özdeşim kurduğu; bunu sebebinin de öğrencilerin kahramanın yaşadıklarına benzer olayları yaşadıklarını veya benzer durumlarda gösterecekleri tepkilerin benzer olacağını belirttiklerini; bu sebeplerle çalışma kapsamında incelenen öykünün çocuk edebiyatının temel ilkelerinden "kahramanla özdeşim kurma" ilkesiyle bağdaştığını ifade etmiştir. Arıkan'ın (2018) çalışmasının sonuçları da araştırmamızın sonuçları ile paralellik göstermektedir.

\section{5. Öneriler}

Çalışmanın sonuçlarına göre şunlar önerilmektedir:

1. Boğaziçi’nde Saklambaç adlı esere yönelik farklı çocuk-okur gruplarıyla da benzer çalışmalar yapılarak veriler karşılaştırılabilir.

2. Boğaziçi’nde Saklambaç adlı eserden hareketle temel dil becerilerine yönelik betimsel ve uygulamalı çalışmalar yapılabilir.

3. Yazarın diğer eserleri ile ilgili benzer çalışmalar yapılabilir.

4. Bilim ve Sanat Merkezi öğrencileri ile aynı kitap hakkında yaş grubu bakımından daha kapsamlı bir çalışma yapılabilir.

5. Bu çalışma örgün eğitim kurumlarında gerçekleştirilebilir.

6. Bu çalışma, Türkçe öğretmenleri ile de gerçekleştirilip çocuk okurlardan elde edilen verilerle karşılaştırmalı bir çalışma yapılabilir.

7. Çocuk edebiyatının temel ilkelerine uygun olması sebebiyle kitap, Millî Eğitim Bakanlığının tavsiye eserler listesi içerisine alınabilir. alınabilir.

8. Yazarın kitabından bölümler Türkçe ders kitapları okuma metinleri kapsamına 
9. Diğer yazarların aynı yaş grubuna seslenen yapıtlarıyla da benzer çalışmalar yap1labilir.

\section{Kaynakça}

Arıkan B. (2018). Çocuk Edebiyatının Temel İlkeleri Bakımından Memduh Şevket Esendal'ın Öykülerinin Öğrenci Görüşlerine Göre Değerlendirilmesi, Yayımlanmamış Yüksek Lisans Tezi, Gaziantep Üniversitesi, Eğitim Bilimleri Enstitüsü, Sosyal Bilgiler ve Türkçe Eğitimi Ana Bilim Dalı, Gaziantep.

Ateş, M. (2004). Ziya Gökalp'ın Çocuk Edebiyatıyla İlgili Görüşleri ve Eserleri, Yayımlanmamış Yüksek Lisans Tezi, Selçuk Üniversitesi, Sosyal Bilimler Enstitüsü, Türkçe Eğitimi Anabilim Dalı, Türkçe Öğretmenliği Bilim Dalı, Konya.

Bildiren, A. (2011). Üstün Yetenekli Çocuklar, Aileler ve Öğretmenler İçin Bir Kılavuz, İstanbul: Doğan Yayıncilık.

Burç, B. (2013). Rıfat Ilgaz'ın “Bacaksız’ın Basından Geçenler” Adlı Hikâye Serisindeki Eserlerin Çocuğa Görelik İlkesi Açısından İncelenmesi, Yayımlanmamış Yükssek Lisans Tezi, Fırat Üniversitesi, Eğitim Bilimleri Enstitüsü, Türkçe Eğitimi Anabilim Dalı, Elazığ.

Baş, B. (2015). Türkçe Öğretimi Açısından Çocuk Edebiyatı, Ankara: Pegem Akademi Yayınları.

Çer, E. (2014). Edebiyatta Çocuk Gerçekliği ve Çocuğa Görelik İlkelerinin İncelenmesi, Yayımlanmamış Doktora Tezi, Ankara Üniversitesi Eğitim Bilimleri Enstitüsü, Eğitimin Kültürel Temelleri Anabilim Dalı, Güzel Sanatlar Eğitimi Bilim Dalı, Ankara.

Derman, S. (2002). Anadil (Türkçe) Öğretiminde Masal Metinlerinin Kullanılması, Yayımlanmamış Yüksek Lisans Tezi, Selçuk Üniversitesi, Sosyal Bilimler Enstitüsü, Türkçe Eğitimi Anabilim Dalı, Türkçe Öğretmenliği Bilim Dalı, Konya.

Dilidüzgün, S. (2004). Okuma Öğretimi Hedefleri Bağlamında Türkçe Ders Kitaplarındaki Çocuk Edebiyatı Ürünleri, Hasan Ali Yücel Eğitim Fakültesi Dergisi Sayı 2 (2004), 43-55.

Genç, M. A. (2013). Üstün Yetenekli Öğrencilerin Görsel Sanatlar Eğitiminde Disiplinleraras1 Öğretim Etkinliklerinin Değerlendirilmesi, (Konya Bilsem Örneği), Doktora Tezi, Selçuk Üniversitesi Eğitim Bilimleri Enstitüsü Güzel Sanatlar Eğitimi Ana Bilim Dalı Resim-İşs Eğitimi, Konya.

Gönen M. ve Veziroğlu M. (2019). Erken Çocukluk Döneminde Çocuk Edebiyat1, Ankara: Eğiten Kitap Yayıncılık.

Hunt, P. (2005). International Companion Encyclopedia Of Children's Literature. Routledge, London.

Karasar, N. (2017). Bilimsel Araştırma Yöntemi: Kavramlar, İlkeler, Teknikler, Ankara: Nobel Akademik Yayıncılık.

Kirazlı, N. (2018). Behiç Ak'ın Çocuk Edebiyatı Yapıtlarının Çocuğa Görelik Açısından İncelenmesi, Yayımlanmamış Yüksek Lisans Tezi, Ankara Üniversitesi, Eğitim Bilimleri Enstitüsü, Eğitimin Kültürel Temelleri Anabilim Dalı, Türkçe Eğitimi Programı, Ankara.

Küçükyılmaz, A., Duban, N. (2006). Sınıf Öğretmeni Adaylarının Fen Öğretimi Öz-Yeterlik İnançlarının Artırılabilmesi İçin Alınacak Önlemlere İlişkin Görüşleri, Yüzüncü Yı1 Üniversitesi, Eğitim Fakültesi Dergisi. Aralık, Cilt: II1, Sayı:II, 1-23. 
Levent F. (2011). Üstün Yeteneklilerin Eğitimine Yönelik Görüş ve Politikaların İncelenmesi, Doktora Tezi, Marmara Üniversitesi, Eğitim Bilimleri Enstitüsü, Eğitim Bilimleri Ana Bilim Dalı, Eğitim Yönetimi ve Denetimi Bilim Dalı, İstanbul.

MEB (2015). Millı̂ Eğitim Bakanlığı Özel Eğitim ve Rehberlik Hizmetleri Genel Müdürlüğü Bilsem Yönergesi (26.08.2015 tarihli ve 10096465-20-E.8422166 sayılı Bilsem Yönergesi.

Millî Eğitim Bakanlığı. (2018). İlköğretim Türkçe dersi (6., 7 ve 8. Sinıflar) Öğretim Programı, Ankara: Millî Eğitim Basımevi.

Robinson A., Shore B. ve Enersen L. (2014). Üstün Zekâlılar Eğitiminde En İyi Uygulamalar/Kanıt Temelli Bir Kılavuz. (Çeviri Editörleri: Üzeyir Ogurlu, Fatih Kaya), Ankara: Nobel Akademik Yayıncilik.

Sever, S. (2017). Çocuk Edebiyatı ve Okuma Kültürü, İzmir: Tudem Yayınları.

Şirin, M. R. (2007). Çocuk Edebiyatı Kültürü. Okuma Alışkanlığı ve Medya Sarmalı. Ankara: Kök Yayınc1lik.

Yalçın A., Aytaş, G. (2017). Çocuk Edebiyatı, Ankara: Akçağ Yayıncılık.

Yıldırım, A., Şimşek, H. (2016). Nitel Araştırma Yöntemleri, Ankara: Seçkin Yayıncılık. 